\title{
Relationship between Nodal Position and Plant Age on the Nutrient Composition of Vegetative Poinsettia Leaves
}

\author{
John M. Dole ${ }^{1}$ and Harold F. Wilkins ${ }^{2}$ \\ Department of Horticultural Sciences and Landscape Architecture, University of Minnesota, St. \\ Paul, MN 55108 \\ Additional index words. Euphorbia pulcherrima, boron, calcium, copper, iron, magnesium, manganese, nitrogen, \\ phosphorus, potassium, zinc, tissue analysis
}

\begin{abstract}
Vegetative, single-stem poinsettia plants (Euphorbia pulcherrima Willd. 'Gutbier V-14 Glory') were allowed to develop 10, 15, or 20 nodes (nodal groups). Within each nodal group, blades from the same node position were removed, combined into one sample per node, and analyzed for nutrient content. Nutrient concentrations were found to be distributed within the plant in one of three patterns: 1) N, P, and K concentrations were higher in upper than in lower leaves; 2) $\mathrm{Ca}, \mathrm{Mg}, \mathrm{Fe}, \mathrm{Mn}$, and $\mathrm{B}$ concentrations were higher in lower than in upper leaves; and 3) $\mathrm{Cu}$ and $\mathrm{Zn}$ concentrations were higher in upper and lower leaves than in middle leaves. When 10, 15, and 20 noded groups were compared, the distributional patterns were similar, but actual nutrient concentrations between groups differed. Leaf $\mathrm{P}, \mathrm{Ca}, \mathrm{Mg}, \mathrm{Fe}, \mathrm{Mn}, \mathrm{Zn}$, and $\mathrm{B}$ concentrations increased over time. However, concentrations of $\mathrm{N}, \mathrm{K}$, and $\mathrm{Cu}$ were highest in 43-day-old leaves and lowest in 19-day-old leaves for $\mathrm{N}$ and $\mathrm{Cu}$ and lowest in 67-day-old leaves for K.
\end{abstract}

Tissue nutrient analysis of poinsettia has been widely used in nutritional studies, but results can be influenced by such major factors as nutrient regime (Boodley, 1976, 1977; Conover and Vines, 1972; Cox and Seeley, 1980, 1983, 1984; Criley and Parvin, 1978; Holcomb and Williams, 1980; Joiner and Sheehan, 1964; Kofranek et al., 1956; Link and Shanks, 1957; Shanks and Link, 1957; Tsutsui and Aoki, 1981), medium pH (Tsutsui and Aoki, 1981), medium type (Carlson and Sink, 1967; Seeley, 1978), presence of mycorrhizae (Kaye et al., 1984), growth regulator application (Brown, 1963; Conover and Vines, 1972; Joiner and Sheehan, 1964; Nell and Barrett, 1986), cultivar (Boodley, 1976, 1977; Link and Shanks, 1957), temperature (Senecal and Dansereau, 1985), and foliar nutrient application (Meyer and Boodley, 1967; Morton and Boodley, 1969). Different nutrient levels also have been associated with various poinsettia tissues (Hendriks and Scharpf, 1984; Paulowski et al., 1970; Tsutsui and Aoki, 1981), and disorders, including marginal bract necrosis (Nell and Barrett, 1986), leaf edge burn, (Bierman et al., 1990), "rabbit tracks"' (Hendriks and Scharpf, 1984), and delayed flowering (Shanks and Link, 1957). In the studies that used leaves for analysis, the most recently mature or expanded leaf was commonly used (Carlson and Sink, 1967; Cox and Seeley, 1980, 1983, 1984; Joiner and Sheehan, 1964; Kaye et al., 1984; Kofranek et al., 1956; Seeley, 1978; Senecal and Dansereau, 1985). However, other studies used whole plants (Boodley, 1974), leaves from the middle third of the plants (Conover and Vines, 1972; Holcomb and Williams, 1980; Link and Shanks, 1957; Meyer and Boodley, 1967; Senecal and Dansereau, 1985; Shanks and Link, 1957), or, simply, mature leaves

Received for publication 6 Aug. 1990. Minnesota Agricultural Experiment Station, Scientific Journal Series, Paper no. 16,331. This research was supported in part by Paul Ecke Poinsettias. The authors appreciate the discussion and ideas of Carl Rosen on the research project. The cost of publishing this paper was defrayed in part by the payment of page charges. Under postal regulations, this paper therefore must be hereby marked advertisement solely to indicate this fact.

${ }^{1}$ Assistant Professor, Dept. of Horticulture and Landscape Architecture, Oklahoma State Univ., Stillwater, OK 74078.

${ }^{2}$ Professor. Current address: Nurseryman's Exchange, 2651 Cabrillo Highway North, Half Moon Bay, CA 94019.
(Cox and Seeley, 1980, 1984; Criley and Parvin, 1978; Kofranek et al., 1956; Morton and Boodley, 1967; Seeley, 1978; Senecal and Dansereau, 1985). While the analysis of leaves from various positions may be valid within each study, comparisons between studies are difficult.

Leaf nodal position or developmental stage influenced the concentration of nutrients in poinsettia leaves (Brown, 1963; Cox and Seeley, 1980, 1984; Kofranek et al., 1956; Seeley, 1978; Tsutsui and Aoki, 1981), but the authors reached varied conclusions. Kofranek et al. (1956) found a lower concentration of $\mathrm{K}, \mathrm{Ca}$, and $\mathrm{Mg}$ in the lower than in the most recently matured leaves. In contrast, Tsutsui and Aoki (1981) compared upper, middle, and lower leaves and found $\mathrm{P}, \mathrm{Ca}$, and $\mathrm{Mg}$ levels highest in the lower leaves and lowest in the upper leaves. Results also varied on the influence of plant age on foliar nutrient concentration (Boodley, 1974; Conover and Vines, 1972; Cox and Seeley, 1983; Criley and Parvin, 1978; Seeley, 1978).

The objective of the study was to determine the influence of nodal position and plant age on the foliar nutrient levels of vegetative poinsettia plants.

\section{Materials and Methods}

Rooted 'Gutbier V-14 Glory' cuttings (Paul Ecke Poinsettias, Encinitas, Calif.) were planted into $10-\mathrm{cm}(450-\mathrm{ml})$ pots using an unamended mixture of 3 peat : 1 perlite : 1 soil (by volume) on $22 \mathrm{Apr}$. 1986. Plants were grown in a glasshouse with day/ night minima of $23 / 20 \mathrm{C}$. Plants were kept vegetative by a 4 hr night interruption (2200-0200 HR) from incandescent lamps.

Two weeks after potting, uniform, single-stem plants were selected and divided into three groups of 35 plants each. The leaf blades of each plant were harvested when the average number of nodes for each nodal group reached 10,15 , or 20 . Nodes were numbered from top to bottom, starting with the first leaf unfolded from the apical cone. Within each nodal group, leaf blades from nodes of the same location were removed, combined into one sample per node, and analyzed for nutrient content. Leaves from nodes one and two were immature and combined to make one sample of sufficient weight for analysis.

Leaf tissue was gently rinsed in distilled water, dried, and analyzed using an inductively coupled plasma spectrometer (Univ. 
of Minnesota Soil and Tissue Testing Laboratory) for total B, $\mathrm{Ca}, \mathrm{Cu}, \mathrm{Fe}, \mathrm{Mg}, \mathrm{Mn}, \mathrm{P}, \mathrm{K}$, and $\mathrm{Zn}$ (Munter et al., 1984). The $\mathrm{N}$ concentration was determined by a Kjeldahl method (Carlson, 1978). The experiment was replicated two more times, commencing on 20 May 1986 and 9 Feb. 1988. Plants were placed in a completely randomized design. Data presented were the combined means of three replications of 35 plants per nodal group.

To determine differences due to plant age, data from the lowest five leaves of each nodal group were analyzed by the general linear model (GLM) procedure (SAS Institute, Cary, N.C.). The 10-, 15-, and 20-node plants were harvested an average of 19, 43, and 67 days after planting, respectively.

Constant liquid fertilization was applied during weekdays and plain water on weekends. A solution of $\left(\mathrm{mg} \cdot \cdot_{\left.1 t e r^{-1}\right)} 200 \mathrm{~N}, 44\right.$ $\mathrm{P}$, and $166 \mathrm{~K}$ made from a commercial $20 \mathrm{~N}-10 \mathrm{P}-20 \mathrm{~K}$ product was supplemented with monthly applications of S.T.E.M. (W.R. Grace, Fogelsville, Pa.) at $300 \mathrm{mg} \cdot \mathrm{liter}^{-1}$ and $\mathrm{MgSO}_{4}$ at 600 $\mathrm{mg} \cdot \mathrm{liter}^{-1}$. Standard insect and disease control programs were followed. All fungicides were applied as drenches so as to not contaminate the foliage.

\section{Results}

Nodal position. Nutrient ion concentrations were found to be distributed within the plant in one of three patterns: 1) N, P, and $\mathrm{K}$ concentrations were higher in upper than in lower leaves (Fig. 1); 2) $\mathrm{Ca}, \mathrm{Mg}, \mathrm{Fe}, \mathrm{Mn}$, and $\mathrm{B}$ concentrations were higher

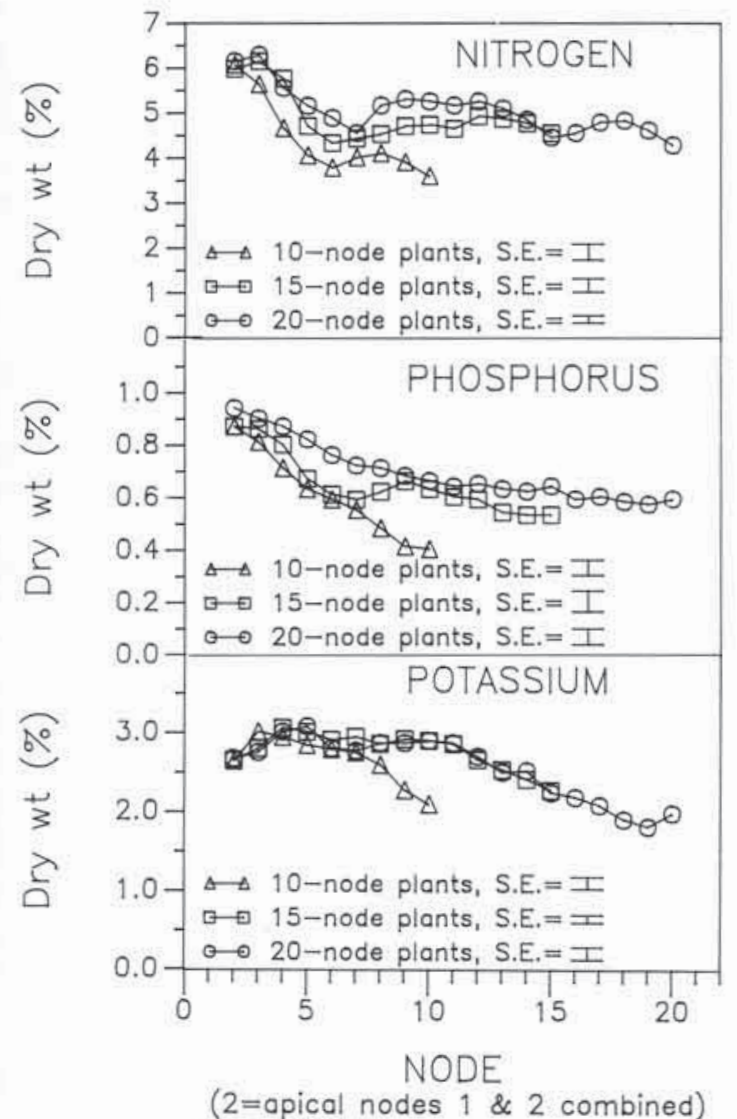

Fig. 1. Average N, P, and $\mathrm{K}$ concentration (dry-weight basis) in 'Gutbier V-14 Glory' poinsettia leaves from each node of 10-, 15-, and 20 -noded plants. Means were for three replications of 35 plants each. Vertical bars represent pooled standard errors for cumulative nutrient ion levels.

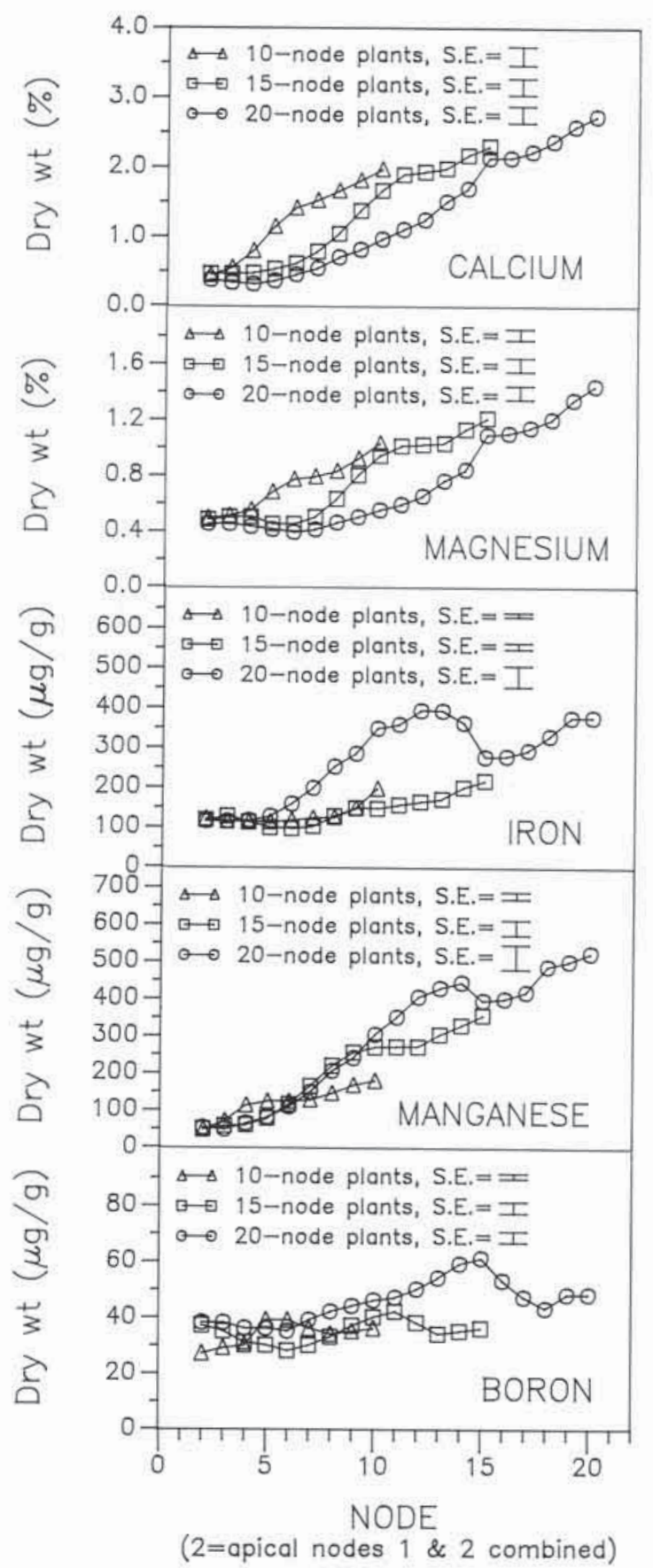

Fig. 2. Average $\mathrm{Ca}, \mathrm{Mg}, \mathrm{Fe}, \mathrm{Mn}$, and $\mathrm{B}$ concentration (dry-weight basis) in 'Gutbier V-14 Glory' poinsettia leaves from each node of $10-, 15-$, and 20-noded plants. Means were for three replications of 35 plants each. Vertical bars represent pooled standard errors for cumulative nutrient ion levels.

in lower than in upper leaves (Fig. 2); and 3) $\mathrm{Cu}$ and $\mathrm{Zn}$ concentrations were higher in upper and lower leaves than in middle leaves (Fig. 3). Nutrient ion concentrations from the second replication tended to be the lowest while concentrations from the first replication were the highest (data not presented). However, each replication produced patterns similar to those described.

Average nutrient concentrations were above critical levels for recently mature leaves as defined by Winsor and Adams (1987) and Ecke et al. (1990) (Table 1), exept for $\mathrm{Ca}$, which will be discussed later. 


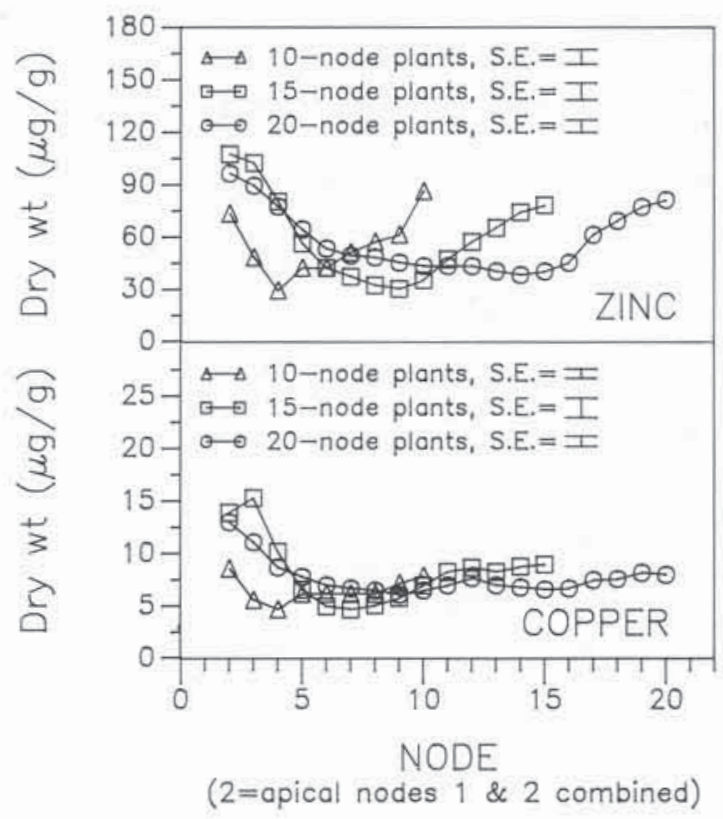

Fig. 3. Average $\mathrm{Zn}$ and $\mathrm{Cu}$ concentration (dry-weight basis) in 'Gutbier V-14 Glory' poinsettia leaves from each node of 10-, 15-, and 20 -noded plants. Means were for three replications of 35 plants each. Vertical bars represent pooled standard errors for cumulative nutrient ion levels.

Table 1. Range of average $\mathrm{N}, \mathrm{P}, \mathrm{K}, \mathrm{Ca}, \mathrm{Mg}, \mathrm{Fe}, \mathrm{Mn}, \mathrm{Zn}, \mathrm{Cu}$, and $\mathrm{B}$ concentrations compared with the critical and optimum concentrations in poinsettia leaves as reported by Winsor and Adams (1987) and Ecke et al. (1990).

\begin{tabular}{|c|c|c|c|c|c|}
\hline \multirow[b]{2}{*}{ Nutrient } & \multirow[b]{2}{*}{ Range } & \multicolumn{2}{|c|}{ Winsor and Adams } & \multicolumn{2}{|c|}{ Ecke et al. } \\
\hline & & Critical & Optimum & Critical & Optimum \\
\hline & & & $\%$ & & \\
\hline $\mathrm{N}$ & $3.77-6.29$ & 2.5 & $4.0-5.5$ & 3.5 & $4.0-6.0$ \\
\hline $\mathrm{P}$ & $0.40-0.94$ & 0.2 & $0.35-0.75$ & 0.15 & $0.3-0.6$ \\
\hline $\mathrm{K}$ & $1.81-3.08$ & 1.5 & $2.5-5.0$ & 1.0 & $1.5-3.5$ \\
\hline $\mathrm{Ca}$ & $0.31-2.73$ & $n a^{2}$ & na & 0.5 & $1.07-1.75$ \\
\hline $\mathrm{Mg}$ & $0.39-1.44$ & 0.25 & $0.35-0.75$ & 0.2 & $0.3-1.0$ \\
\hline $\mathrm{Fe}$ & $96-393$ & na & $\begin{array}{l}\mu g \cdot g^{-1} \\
100-200\end{array}$ & 50 & $100-300$ \\
\hline $\mathrm{Mn}$ & $47-523$ & 25 & $50-200$ & 40 & $60-300$ \\
\hline $\mathrm{Zn}$ & $29-107$ & na & na & 20 & $25-60$ \\
\hline $\mathrm{Cu}$ & $4.6-15.2$ & 4 & $6-15$ & 1 & $2-10$ \\
\hline B & $27-61$ & 25 & $30-80$ & 15 & $25-75$ \\
\hline
\end{tabular}

${ }^{\mathrm{z} N o t}$ available.

Plant age. The $\mathrm{P}, \mathrm{Ca}, \mathrm{Mg}, \mathrm{Fe}, \mathrm{Mn}, \mathrm{Zn}$, and $\mathrm{B}$ concentrations tended to increase with plant age (Table 2). The Ca concentration was significantly higher in 67-day-old leaves than in 19day-old leaves, and in neither were they significantly different from those in 43-day-old leaves. The $\mathrm{Mg}$ concentration was significantly lower in 19-day-old than 43- or 67-day-old leaves, while those in the latter two were not significantly different. The Fe concentration was significantly higher in 67-day-old than in 19- and 43-day-old leaves, while those in the latter two were similar. The Mn concentration was significantly higher in 67day-old than in 43-day-old leaves, which, in turn, was significantly higher than in 19-day-old leaves. The $\mathrm{P}, \mathrm{Zn}$, and $\mathrm{B}$ concentrations were statistically similar for all plant ages.

The $\mathrm{N}, \mathrm{K}$, and $\mathrm{Cu}$ concentrations tended to be higher in 43 day-old leaves than in 19- or 67-day-old leaves (Table 2). The
$\mathrm{N}$ concentration was significantly lower in 19-day-old leaves than in 43- and 67-day-old leaves, while those in the latter two were similar. The $\mathrm{K}$ concentration was significantly lower in 67-day-old leaves than in 19- or 43-day-old leaves, while those in the latter two did not differ significantly. The $\mathrm{Cu}$ concentration was similar regardless of plant age.

\section{Discussion}

Previous studies concerning the effect of developmental stage (Brown, 1963; Cox and Seeley, 1980, 1984; Kofranek et al., 1956; Seeley, 1978; Tsutsui and Aoki, 1981) and plant age (Boodley, 1974; Conover and Vines, 1972; Cox and Seeley, 1983; Criley and Parvin, 1978; Seeley, 1978) on nutrient levels have used a wide range of cultivars, nutrient regimes, growth regulators, media, and temperatures. In addition, all of the previous studies have used reproductive plants, whereas we used vegetative plants. These factors may account for some of the differences between this study and previous studies.

\section{Nitrogen}

Nodal position. Our results, i.e., that $\mathrm{N}$ was highest in upper leaves (Fig. 1), agree with those of Cox and Seeley (1984), Seeley (1978), and Brown (1963). However, Tsutsui and Aoki (1981) found middle leaves to contain a higher $\mathrm{N}$ concentration than upper leaves, with lower leaves containing the least $\mathrm{N}$.

Plant age. The $\mathrm{N}$ concentration tended to be lowest in 19 day-old and highest in 43-day-old leaves (Table 2). These results are similar to those of Boodley (1974). In contrast, Conover and Vines (1972) samples leaves numbered 6-9 from the base and found that $\mathrm{N}$ concentration was highest at day 1 and declined over time. Brown (1963) noted that $\mathrm{N}$ concentration increased in older leaves in two studies and decreased in a third study. Cox and Seeley (1983) sampled the most recently mature leaves and reported a similar decline in $\mathrm{N}$ concentration over time in samples collected from the same relative positions.

\section{Phosphorus}

Nodal position. Our results-P highest in upper leaves (Fig. 1) -are similiar to those of Brown (1963). In contrast to our data, Seeley (1978) and Tsutsui and Aoki (1981) found upper leaves to contain the lowest $\mathrm{P}$ concentration and lower leaves the highest.

Plant age. The $\mathrm{P}$ concentration tended to increase with plant age (Table 2). However, Boodley (1974), Conover and Vines (1972), Cox and Seeley (1983), and Seeley (1978) noted a decline in $\mathrm{P}$ concentration in progressively older leaf samples.

\section{Potassium}

Nodal position. Our results-highest levels in upper leaves (Fig. 1)-agree with those of Kofranek et al. (1956). However, Seeley (1978) compared recently mature leaves, lower leaves on the branches, and the leaf immediately below the pinch and found the lowest $\mathrm{K}$ concentration in the leaf immediately below the pinch and the highest in lower leaves on the branches.

Plant age. The $\mathrm{K}$ concentration tended to be lowest in the 67-day-old leaves and highest in the 43-day-old leaves (Table 2). These results were similar to those of Boodley (1974), Conover and Vines (1972), Cox and Seeley (1983), and Seeley (1978).

Concentrations of $\mathrm{Ca}, \mathrm{Mg}, \mathrm{Fe}, \mathrm{Mn}$, and $\mathrm{B}$ were highest in lower leaves and all increased significantly with plant age except 
Table 2. Average $\mathrm{N}, \mathrm{P}, \mathrm{K}, \mathrm{Ca}, \mathrm{Mg}, \mathrm{Fe}, \mathrm{Mn}, \mathrm{Zn}, \mathrm{Cu}$, and $\mathrm{B}$ concentrations in the lowest five leaves of 10-, 15-, and 20 -node vegetative 'Gutbier V-14 Glory' poinsettia plants. Nodes were numbered from top to bottom; youngest leaf was at node 1 . Means are for three replications of 35 plants each.

\begin{tabular}{|c|c|c|c|c|c|c|c|c|c|c|c|}
\hline \multirow{2}{*}{$\begin{array}{l}\text { Total } \\
\text { nodes per } \\
\text { plant }\end{array}$} & \multirow{2}{*}{$\begin{array}{c}\text { Average } \\
\text { no. of } \\
\text { days from } \\
\text { planting to } \\
\text { harvest }\end{array}$} & \multirow{2}{*}{$\begin{array}{c}\text { Inclusive } \\
\text { nodes for } \\
\text { harvested } \\
\text { leaves }\end{array}$} & \multicolumn{9}{|c|}{ Nutrient } \\
\hline & & & $\mathrm{N}$ & $\mathrm{P}$ & $\mathrm{K}$ & $\mathrm{Ca}$ & $\mathrm{Mg}$ & $\mathrm{Fe}$ & $\mathrm{Mn} \mathrm{Zn}$ & $\mathrm{Cu}$ & B \\
\hline & & & \multicolumn{5}{|c|}{$\%$} & \multicolumn{4}{|c|}{$\mu g \cdot g^{-1}$} \\
\hline $\begin{array}{l}10 \\
15\end{array}$ & 19 & $5-10$ & 3.87 & 0.49 & 2.50 & 1.67 & 0.89 & 142 & $\begin{array}{ll}149 & 58 \\
306 & 64\end{array}$ & $\begin{array}{r}6.6 \\
0.5\end{array}$ & $\begin{array}{l}36 \\
37\end{array}$ \\
\hline $\begin{array}{l}15 \\
20\end{array}$ & $\begin{array}{l}43 \\
67\end{array}$ & $\begin{array}{l}10-15 \\
15-20\end{array}$ & $\begin{array}{l}4.74 \\
4.60\end{array}$ & $\begin{array}{l}0.56 \\
0.59\end{array}$ & $\begin{array}{l}2.55 \\
1.99\end{array}$ & $\begin{array}{l}2.05 \\
2.41\end{array}$ & $\begin{array}{l}1.08 \\
1.24\end{array}$ & $\begin{array}{l}182 \\
330\end{array}$ & $\begin{array}{ll}306 & 64 \\
466 & 67\end{array}$ & $\begin{array}{l}8.5 \\
7.5\end{array}$ & $\begin{array}{l}37 \\
48\end{array}$ \\
\hline Significance & & & $* * *$ & NS & $* *$ & $*$ & $* * *$ & $* * *$ & $* * *$ NS & NS & NS \\
\hline HSD $(0.05)$ & & & 0.54 & 0.20 & 0.39 & 0.57 & 0.17 & 81 & $134 \quad 35$ & 3.5 & 14 \\
\hline
\end{tabular}

NS,*,**,***Nonsignificant or significant at $P=0.05,0.01$, or 0.001 , respectively.

for B, which showed a statistically insignificant increase (Fig. 2, Table 2).

\section{Calcium}

Nodal position. Our data are similar to those of Seeley (1978) and Tsutsui and Aoki (1981) in that Ca concentrations were lowest in upper leaves (Fig. 2). However, Kofranek et al. (1956) found higher $\mathrm{Ca}$ concentration in upper than in lower leaves.

Plant age. Our results (Table 2) agree with those of Conover and Vines (1972) and Cox and Seeley (1983). Boodley (1974) and Seeley (1978), however, noted a decline in Ca levels in progressively older leaf samples.

The average $\mathrm{Ca}$ concentrations for the upper 1,3 , and 5 nodes of the 10,15 , and 20 noded groups (Table 2), respectively, were below the critical $0.5 \%$ level suggested by Ecke et al. (1990), but no deficiency symptoms were noted. Therefore, sampling of less than mature leaves may erroneously indicate low $\mathrm{Ca}$ levels in the plant.

\section{Magnesium}

Nodal position. Our data (Fig. 2) agree with those of Seeley (1978) and Tsutsui and Aoki (1981). However, Cox and Seeley (1980) compared recently mature leaves, leaves that had matured after planting, and basal leaves that were present on the original cutting. They noted that if the medium contained adequate amounts of $\mathrm{Mg}$, leaves that matured after planting contained $\mathrm{Mg}$ concentrations equal to or greater than recently mature leaves, and basal leaves contained the highest concentration.

Plant age. In contrast to us (Table 2), Boodley (1974) and Conover and Vines (1972) found the $\mathrm{Mg}$ concentration to remain constant throughout the sampling period. Seeley (1978) noted a decline in $\mathrm{Mg}$ concentration with later sampling dates. Cox and Seeley (1983) noted a K-Mg interaction in that the $\mathrm{Mg}$ concentration remained constant throughout the sampling period when plants were supplied with $300 \mathrm{ppm} \mathrm{K}$ but increased in later samples when plants were supplied with only $30 \mathrm{ppm}$.

\section{Iron}

The Fe concentrations were highest in the lower leaves (Fig. 2 ) and they increased with plant age (Table 2). In contrast, Conover and Vines (1972) found no significant differences in Fe concentrations due to leaf age.

\section{Manganese}

We noted that the Mn concentration was highest in lower leaves (Fig. 2) and increased with plant age (Table 2). In con- trast to our data, those of Conover and Vines (1972) showed that the Mn concentration was highest at day 1 , declined at days 4 and 8 , but increased slightly at days 16 and 32 .

\section{Boron}

Our results agree with those of Kofranek et al. (19j6) who noted higher B levels in lower than in upper leaves (Fig. 2). Whereas we found B to increase with time (Table 2), Criley and Parvine (1978), who sampled at two dates 1 month apart, found a higher B concentration on the first than on the second date.

\section{Copper}

The $\mathrm{Cu}$ concentration was lowest in the middle leaves (Fig. 3 ). Also, the $\mathrm{Cu}$ concentration tended to be highest in 43-dayold and lowest in the 19-day-old leaves (Table 2). Conover and Vines (1972) found no significant difference in Cu concentration due to leaf age.

\section{Zinc}

The $\mathrm{Zn}$ levels were lowest in the middle leaves (Fig. 3), and tended to increase with plant age (Table 2), but Conover and Vines (1972) found no significant difference in $\mathrm{Zn}$ concentration due to leaf age.

In summary, consistency in regard to nodal position and plant age is critical for diagnosis of nutrient status in poinsettia. Current standards for poinsettia tissue tests are based on the most recently mature leaves (Windsor and Adams, 1987; Ecke et al., 1990). However, with $\mathrm{Ca}, \mathrm{Mg}, \mathrm{Fe}, \mathrm{Mn}, \mathrm{Zn}, \mathrm{Cu}$, and $\mathrm{B}$, relatively large variations in leaf nutrient content could result from changing the sampling position only a few nodes (Figs. 2 and 3 ). Leaf age should also be considered when recently mature leaves are not available, such as on reproductive or recently pinched plants. Comparing the nutrient levels of mature leaves from these plants with the reported standard levels, based on recently mature leaves, may lead to incorrect conclusions. With recently pinched plants, samples should be taken after recently mature leaves are produced on new shoots. Tissue testing can be a powerful tool in preventing or diagnosing nutritional problems, but samples must be taken carefully to insure that valid comparisons can be made with reported standards and within experimental treatments. In addition, potential differences in results due to nutrient regime, media type, medium $\mathrm{pH}$, presence of mycorrhizae, growth regulator application, cultivar, temperature and foliar nutrient application must also be considered. 


\section{Literature Cited}

Bierman, P.M., C.J. Rosen, and H.F. Wilkins. 1990. Leaf edge burn and axillary shoot growth of vegetative poinsettia plants: Influence of calcium, nitrogen form, and molybdenum. J. Amer. Soc. Hort. Sci. 115(1):73-78.

Boodley, J.W. 1974. Nutrient content of Paul Mikkelsen poinsettias from juvenile to mature growth. Florists Rev. 155(4021):26-27, 6973.

Boodley, J.W. 1976. Poinsettia nutrition studies, 1976. N.Y. State Flower Industries Bul. 88:3-4, 7.

Boodley, J.W. 1977. Some effects of three trace element fertilizers on the growth of nine cultivars of poinsettias. N.Y. State Flower Industries Bul. 89:3-4, 7-8.

Brown, H.C. 1963. The effect of Cycocel ((2-chloroethyl) trimethylammonium chloride) applied to the soil on the inhibition of growth and mineral element content of the foliage of potted poinsettias (Euphorbia pulcherrima Willd.). $\mathrm{PhD}$ Diss., Ohio State Univ., Columbus.

Carlson, R.M. 1978. Automatic separation and conductimetric determination of ammonia and dissolved carbon dioxide. Anal. Chem. $50: 1528-1532$.

Carlson, W.H. and K.C. Sink. 1967. The effect of soil mixes on poinsettia variety Paul Mikkelsen. Quart. Bul. Mich. Agr. Expt. Sta. 50:20-24.

Conover, C.A. and H.M. Vines. 1972. Chlormequat drench and spray applications to poinsettias. J. Amer. Soc. Hort. Sci. 97(3):316-320.

Cox, D.A. and J.G. Seeley. 1980. Magnesium nutrition of poinsettia. HortScience 15(6):822-823.

Cox, D.A. and J.G. Seeley. 1983. The effect of nitrogen and potassium fertilization and sample date on the macronutrient composition of poinsettia leaves. HortScience 18(5):751-752.

Cox, D.A. and J.G. Seeley. 1984. Ammonium injury to poinsettia: effects of $\mathrm{NH}_{4}-\mathrm{N}: \mathrm{NO}_{3}-\mathrm{N}$ ratio and $\mathrm{pH}$ control in solution culture on growth, $\mathrm{N}$ absorption, and $\mathrm{N}$ utilization. J. Amer. Soc. Hort. Sci. 109(1):57-62.

Criley, R.A. and P.E. Parvin. 1978. Effect of nutrient regimes and minor elements on the growth and tissue composition of poinsettia cultivars in soilless mediums. Hawaii Agr. Expt. Sta. Dept. Paper no. 53.

Ecke, P., Jr., O.A. Matkin, and D.E. Hartley. 1990. The poinsettia manual, 3rd ed. Paul Ecke Poinsettias, Encinitas, Calif.

Hendriks, L. and H.C. Scharpf. 1984. "'Geisterflecken'” an Poinsettien sind vermeidbar. Deutscher Gartenbau. 49:2201-2204.
Holcomb, E.J. and S. Williams. 1980. The effect of slow-release fertilizers on poinsettias. Penn. Flower Growers Bul. 324:1, 6-7.

Joiner, J.N. and T.J. Sheehan. 1964. The growth and biochemical responses of 'Barbara Ecke Supreme' poinsettias to nitrogen and growth retardants. Proc. Fla. State Hort. Soc. 77:523-525.

Kaye, J.W., F.L. Pfleger, and E.L. Stewart. 1984. Interaction of Glomus fasciculatum and Phythium ultimum on greenhouse-grown poinsettia. Can. J. Bot. 62:1575-1579.

Kofranek, A.M., O.R. Lunt, and H.C. Kohl. 1956. Tolerance of poinsettias to saline conditions and high boron concentrations. Proc. Amer. Soc. Hort. Sci. 68:551-555.

Link, C.B. and J.B. Shanks. 1957. The mineral nutrition of poinsettia stock plants in the greenhouse. Proc. Amer. Soc. Hort. Sci. 69:502512.

Meyer, M.M., Jr., and J.W. Boodley. 1967. Foliar applications of nitrogen, phosphorus, and potassium to chrysanthemum and poinsettia. Proc. Amer. Soc. Hort. Sci. 84:582-587.

Morton, W.M. and J.W. Boodley. 1969. Effect of mist-fertilizer propagation on the growth and nutrient content of Euphorbia pulcherrima and Chrysanthemum morifolium. J. Amer. Soc. Hort Sci. 94:549553.

Munter, R.C., T.L. Halversen, and R.P. Anderson. 1984. Quality assurance for plant tissue analysis by ICP-AES. Commun. Soil Sci. Plant Anal. 15:1285-1322.

Nell, T.A. and J.E. Barrett. 1986. Growth and incidence of bract necrosis in 'Gutbier V-14 Glory' poinsettia. J. Amer. Soc. Hort. Sci. 11(2):266-269.

Paulowski, H.E., P. Schwandt, and D. Alt. 1970. Cycocel und N Düngung verbessern die Qualität von Poinsettien 'Annette Hegg.' Gartenwelt 70:519-521.

Seeley, J.G. 1978. Potassium nutrition of poinsettias and effect of two peat-lite mixes. N.Y. State Flower Industries Bul. 90:1, 3-4, 6-7.

Senecal, M. and B. Dansereau. 1985. Influence of cold pretreatment and night temperature on the growth, development, and mineral content of poinsettia plants. Can. J. Plant Sci. 65:1001-1010.

Shanks, J.B. and C.B. Link. 1957. The mineral nutrition of poinsettias for greenhouse forcing. Proc. Amer. Soc. Hort. Sci. 69:513-522.

Tsutsui, K. and M. Aoki. 1981. Response of poinsettias to major nutrient supply in relation to nutrient uptake and growth. Bul. Veg. \& Orn. Crops Res. Sta. Ano Jpn. Ser. A 8:171-207.

Winsor, G. and P. Adams. 1987. Glasshouse crops, p. 100-105, 162166. In: J.B.D. Robinson (ed.). Diagnosis of mineral disorders in plants, vol. 3. Chemical Publishing, New York. 